\title{
Faktor-Faktor yang Mempengaruhi Mahasiswa/i Memilih Program Studi Pariwisata Jurusan Pariwisata di Politeknik Negeri Samarinda
}

\author{
Sabalius Uhai ${ }^{1, *}$, Rini Koen Iswandari ${ }^{\text {a, }}$, Musdalifah ${ }^{\text {a,3 }}$, Rina Oktavianti a,4 \\ ${ }^{1}$ sabaliusuhai@polnes.ac.id*; ${ }^{2}$ rini02@polnes.ac.id; ${ }^{3}$ musda14@polnes.ac.id; \\ a Jurusan Pariwisata Politeknik Negeri Samarinda, Alamat, Kota Samarinda 75131, Indonesia \\ 1,2 Jl. DR. Ciptomangunkusumo, Kampus Gunung Lipan, Samarinda, Kalimantan Timur, Indonesia 75131 \\ | Hot line: PABX (+62541) 260588, FAX: (+62541) 260355 \\ * corresponding author
}

ARTICLE INFO

Article history:

Submitted: May 15, 2020

Reviewed: May 30, 2020

Accepted: June 8, 2020

Published: June 30, 2020

Keywords:Individual personality, job prospect, college image, family support and the decision to choose tourism major

\section{ABSTRACT}

This study aims to determine whether individual personality factors, job prospect factors, college image factors, and family support factors simultaneously influence the decision to choose a tourism study program at the Department of Tourism in Samarinda State Polytechnic? Do individual personality factors, job prospect factors, college image factors, and family support factors partially influence the decision to choose a tourism study program at the Department of Tourism in Samarinda State Polytechnic? This study uses multiple regression analysis and is used to analyze the results of the study. HI accepted Then the individual personality factor variable has a dominant influence on the decision to choose a tourism study program, it can be seen that the tcount> ttable is $(6,844)>(1,664)$ and a significant value of 0,000>0,005. With the regression coefficient value is positive that is equal to 0, 414. H1 is accepted then the prospect of employment affects the decision to choose a tourism study program, it can be seen that the tcount> ttable is (2.581)> (1,664) and a significant value of $0.01<0.05$. The regression coefficient value is positive at 0.277 . H1 is accepted, then the image of the college influences the decision to choose tourism study programs, it can be seen that the value of tcount> ttable (1.432) <(1.664) With the positive coefficient of regression is 0.097 $\mathrm{HI}$ is accepted then family support influences the decision to choose a study program tourism, it can be seen that the value of tcount> ttable is (2.007)> (1,664) and a significant value of $0.04<0.05$. Based on the ANOVA test, a Fcount of 45,947 can be obtained with a significant level of 0,000. Therefore the probability is much smaller than 0.05 (0.000 <0.05) and Fcount> Ftable (45.947> 2.32), so it can be stated that the independent variables include individual personality factors (X1), employment prospect factors (X2), college image factor (X3), and family support factor (X4) simultaneously or jointly influence the decision variable in choosing a tourism study program.

\section{ABSTRAK}

Penelitian ini bertujuan untuk mengetahui Apakah faktor kepribadian individu, faktor prospek lapangan kerja, faktor citra perguruan tinggi, dan faktor dukungan keluarga berpengaruh secara simultan terhadap keputusan memilih program studi pariwisata Jurusan Pariwisata di Polteknik Negeri Samarinda? Apakah faktor kepribadian individu, faktor prospek lapangan kerja, faktor citra
Kata kunci: Kepribadian individu, prospek lapangan kerja, citra perguruan tinggi, dukungan keluarga 
perguruan tinggi, dan faktor dukungan keluarga berpengaruh secara parsial terhadap keputusan memilih program studi pariwisata Jurusan Pariwisata di Polteknik Negeri Samarinda? Penelitian ini menggunakan analisis regresi berganda dan digunakan untuk menganalisis hasil penelitian. H1 diterima Maka variabel faktor kepribadian individu berpengaruh dominan terhadap keputusan memilih program studi pariwisata, hal ini dapat dilihat bahwa nilai thitung > ttabel yaitu $(6,844)>(1,664)$ dan nilai signifikan $0,000>$ 0,005 . Dengan nilai koefisien regresi adalah postif yakni sebesar 0 , 414. H1 diterima maka prospek lapangan kerja berpengaruh terhadap keputusan memilih program studi pariwisata, hal ini dapat dilihat bahwa nilai thitung > ttabel yaitu $(2,581)>(1,664)$ dan nilai signifikan $0,01<0,05$. Dengan nilai koefisien regersi adalah positif yakni 0,277 . H1 diterima maka citra perguruan tinggi berpengaruh terhadap keputusan memilih program studi pariwisata, hal ini dapat dilihat bahwa nilai thitung > ttabel yaitu $(1,432)<(1,664)$ Dengan nilai koefisien regersi adalah positif yakni $0,097 \mathrm{H} 1$ diterima maka dukungan keluarga berpengaruh terhadap keputusan memilih program studi pariwisata, hal ini dapat dilihat bahwa nilai thitung > ttabel yaitu $(2,007)>(1,664)$ dan nilai signifikan $0,04<0,05$. Berdasarkan uji ANOVA maka dapat diperoleh $\mathrm{F}$ hitung sebesar 45,947 dengan tingkat signifikan 0,000 . Oleh karena itu probalitas jauh lebih kecil dari pada $0,05(0,000<0,05)$ dan Fhitung > Ftabel $(45,947>2,32)$ maka dapat dinyatakan bahwa variabel independen yang meliputi faktor kepribadian individu (X1), faktor prospek lapangan kerja (X2), faktor citra perguruan tinggi (X3), dan faktor dukungan keluarga (X4) secara simultan atau bersama-sama mempengaruhi variabel keputusan memilih program studi pariwisata.

Copyright $\odot 2019$ Politeknik Negeri Samarinda. All rights reserved.

\section{Pendahuluan}

Perguruan tinggi merupakan salah satu lembaga penyelenggara pendidikan yang keberadaannya diharapkan mampu menciptakan manusia yang mempunyai nilai tambah dan mampu menghasilkan karyailmiah serta inovasi teknologi(Nuryadin, Muhammad Teguh, Marijati Sangen, 2017)

Pada era globalisasi sekarang ini, perkembangan ilmu pengetahuan dan teknologi mengalami kemajuan yang semakin pesat. Hal ini tentu menyebabkan terjadinya perubahan dalam kehidupan manusia, termasuk persaingan dalam dunia kerja yang semakin tinggi. Oleh sebab itu masyarakat mulai menyadari pentingnya pendidikan pada era globalisasi(S. Lestari, 2018). Pendidikan merupakan pilihan yang tepat untuk peningkatan sumber daya manusia yang berkualitas. Melalui pendidikan, seseorang akan dibina serta dibimbing untuk mengembangkan bakat, minat dan intelektualnya untuk mempersiapkan diri berkarir di masa yang akan datang. Tujuan utama pendidikan adalah perubahan tingkah laku (Rohmat, 2012)

Melalui pendidikan tinggi ini mahasiswa dididik untuk menjadi seseorang yang ahli dalam bidangnya. Salah satu pendidikan tinggi yang melaksanakan program pendidikan Diploma adalah Politeknik Negeri Samarinda. Politeknik Negeri Samarinda adalah sebuah perguruan tinggi negeri yang sebelumnya bernama Politeknik Universitas Mulawarman, yang resmi berdiri berdasarkan Surat Keputusan Direktorat Jenderal Pendidikan Tinggi No.080/Dikti/Kep/85 tertanggal 3 Desember 1985. Politeknik Negeri Samarinda terdapat jurusan antara lain Teknik Sipil, Teknik Mesin, Teknik Kimia, Teknik Elektro, Teknik Informasi, Administrasi Bisnis, Akuntansi, Desain, Kemaritiman dan Pariwisata.

Begitu pula halnya mahasiswa yang memilih program studi Pariwisata. Dari sisi mahasiswa, terdapat banyak faktor untuk menentukan pilihannya dalam memilih program studi. Pemilihan program studi seharusnya sesuai dengan keinginan mahasiswa sesuai dengan minat dan bakatnya. Pemilihan program studi sesuai keinginan tersebut akan memudahkan 
mahasiswa dalam menjalankan perkuliahannya. Pentingnya mengetahui minat dan bakat tersebut akan berdampak baik dan akan dikembangkan saat memilih program studi yang sesuai keinginannya.

Peluang kerja yang dimiliki suatu jurusan ataupun program studi sendiri termasuk dalam pertimbangan seorang mahasiswa dalam memutuskan memilih suatu program studi. Dengan besarnya peluang kerja akan memudahkan mahasiswa mencari pekerjaan saat mereka lulus nanti(Prodjo, n.d.).

Dukungan keluarga juga menjadi faktor seorang mahasiswa dalam memutuskan dimana ia akan melanjutkan pendidikan serta jurusan atau program studi apa yang akan mahasiswa tersebut pilih. Dukungan keluarga yang baik akan membuat mahasiswa nyaman dalam menjalani masa perkuliahannya(Indra Novianto Adibayu Pamungkas, 2019).

\section{Tinjauan Pustaka}

\section{1 Kepribadian}

Kepribadian adalah terjemahan dari bahasa Inggris yang berarti personality. Kata personality sendiri berasal dari bahasa Latin yaitu persona yang berarti topeng yang digunakan oleh para aktor dalam suatu permainan atau pertunjukkan. Sehingga konsep awal dari pengertian personality, adalah tingkah laku yang ditampakkan ke lingkungan sosial, kesan mengenai diri yang diinginkan agar dapat ditangkap oleh lingkungan sosial (Yusuf LN, 2007).

Menurut Anwar (Zainal Anawar, 2012) kepribadian disebut sebagai suatu yang abstrak, sukar dilihat secara nyata, hanya dapat diketahui lewat penampilan, tindakan dan ucapan ketika menghadapi sesuatu persoalan. Kepribadian manusia mencangkup semua unsure baik fisik maupun psikis. Sehingga dapat diketahui bahwa setiap tindakan dan tingkah laku seseorang merupakan cerminan dari kepribadian seseorang.

\subsection{Prospek Lapangan Kerja}

Menurut Kamus Besar Bahasa Indonesia prospek adalah kemungkinan atau harapan. Segala bentuk kejadian yang baik ataupun buruk yang kemungkinan akan terjadi.
Menurut Zarkasyi (M Ridki Zarkasyi, 2013) prospek adalah suatu gambaran keberlangsungan suatu ide di masa depan yang berupa peluang yang masih harus diadaptasikan dengan berbagai keterbatasan dan kondisi yang melingkupinya.

Menurut Paul R. Krugman (Krugman, 2003) menyatakan bahwa prospek adalah peluang yang terjadi karena adanya usaha seseorang dalam memenuhi kebutuhan hidupnya juga untuk mendapatkan profit. Lapangan kerja adalah keadaan yang menggambarkan ketersediaan pekerjaan untuk para pencari kerja. Pekerjaan adalah sebuah karir yang dilakukan dalam sebuah kehidupan yang menghasilkan sebuah karya bernilai imbalan dalam bentuk uang bagi seseorang.

\subsection{Citra Perguruan Tinggi}

Citra adalah total persepsi terhadap suatu objek, yang dibentuk dengan memproses informasi dari berbagai sumber setiap waktu (Setiadi nugroho, 2013).

Merek merupakan salah satu unsur penting yang dapat membantu proses pemasaran disuatu perusahaan. Menurut Kotler definisi merek adalah suatu nama, istilah, tanda, lambang, rancangan, atau kombinasi dari(Philip Kotler, 2010) semuanya, yang dimaksudkan untuk mengindentifikasi barang atau jasa dari seorang penjual atau sekelompok penjual untuk mendiferensiasikan barang atau jasa dari pesaing. Menurut Simamora (Bilson Simamora, 2008) menyatakan bahwa citra adalah persepsi yang relatif konsisten dalam jangka waktu panjang.

Schiffman dan Kanuk (Schiffman, 2011) menyebutkan faktor-faktor pembentuk citra merk adalah sebagai berikut :

1. Kualitas atau mutu, berkaitan dengan kualitas produk barang dan jasa yang ditawarkan oleh produsen dan berkenaan dengan kompetensitenaga pengajar didalamnya dan kemampuan lulusan serta kemudahan lulusan untuk memperoleh pekerjaan.

2. Dapat dipercaya atau diandalkan, berkaitan dengan pendapat atau kesepakatan yang dibentuk oleh masyarakat tentang suatu jasa yang dikonsumsi. 
3. Kegunaan atau manfaat, berkaitan dengan fungsi dari suatu produk atau jasa yang dikonsumsi.

4. Pelayanan, berkaitan dengan tugas produsen atau lembaga pendidikan dalam melayani mahasiswa.

5. Resiko, berkaitan dengan besar kecilnya akibat atau untung rugi yang mungkin dialami oleh konsumen atau mahasiswa setelah memilih suatu perguruan tinggi.

6. Harga, berkaitan dengan tinggi rendahnya atau banyak sedikitnya jumlah biaya yang dikeluarkan konsumen atau mahasiswa untuk menempuh pendidikannya.

7. Citra yang dimiliki oleh merek itu sendiri, berupa pandangan, kesepakatan dan informasi yang berkaitan dengan suatu merek tertentu.

\subsection{Dukungan Keluarga}

Menurut Zuyun Nela (Zuyun Nela, 2013) didalam kehidupan seseorang, keluarga merupakan lingkungan pertama yang dikenal oleh individu dalam proses sosialisasinya. Menurut Friedman (Friedman, 2010) dukungan keluarga merupakan sikap, tindakan penerimaan keluarga terhadap anggota keluarganya, berupa dukungan informasional, dukungan penilaian, dukungan instrumental dan dukungan emosional.

Dukungan diterjemahkan dalam Kamus Besar Bahasa Indonesia(Pendidikan, 2008) sebagai sesuatu yang didukung, sokongan ataupun bantuan. Chaplin (J. P Chaplin, n.d.) mendefinisikan dukungan sebagai pemberian dorongan atau pengobatan semangat dan nasihat kepada orang lain dalam satu situasi pembuatan keputusan. Di sisi lain definisi keluarga menurut Chaplin (J. P Chaplin, n.d.) adalah satu kelompok individu yang terkait oleh ikatan perkawinan atau darah secara khusus, mencakup seorang ayah, ibu, dan anak.

Menurut Sarafino (Sarafino, 2000) menyampaikan lima bentuk dukungan sosial yang dapat digunakan untuk menunjukkan jenis dukungan yang dapat diberikan anggota keluarga kepada anggota keluarga lainnya, yaitu sebagai berikut :
1. Dukungan emosional, mencakup ungkapan empati, kepedulian dan perhatian orang-orang yang bersangkutan. Dukungan emosional merupakan ekspresi dari afeksi, kepercayaan, perhatian, dan perasaan didengarkan. Kesediaan untuk mendengarkan keluhan seseorang akan memberikan dampak positif sebagai sarana pelepasan emosi, mengurangi kecemasan, membuat individu merasa nyaman, tenteram, diperhatikan, serta dicintai saat menghadapi berbagai tekanan dalam hidup mereka. Dukungan emosional ini diberikan keluarga kepada anggota keluarga lainnya dengan menjadi tempat bersandar. Keluarga juga menunjukkan empati dan perhatian dengan turut serta dalam membantu memberikan informasi yang dibutuhkan, dan memberikan dorongan bagi anggota keluarga yang membutuhkan.

2. Dukungan penghargaan, dukungan yang terjadi lewat ungkapan penghargaan yang positif untuk individu, dorongan maju atau persetujuan dengan gagasan atau perasaan individu, dan perbandingan positif individu dengan individu lain, seperti misalnya perbandingan dengan orang-orang yang kurang mampu atau lebih buruk keadaannya. Hal seperti ini dapat menambah penghargaan diri. Keluarga memberikan interaksi dengan anggota keluarga lainnya dengan memberikan dorongan persetujuan akan keputusan yang telah dibuat oleh individu. Keluarga juga dapat memberikan contoh positif dan negatif akan peristiwa yang telah terjadi dari individu lainnya. Dengan begitu, individu akan dapat mengevaluasi dan mempertegas keyakinannya dengan membandingkan pendapat, sikap, keyakinan, dan perilaku orang lain. Jenis dukungan ini membantu individu merasa dirinya berharga, mampu dan dihargai.

3. Dukungan instrumental, mencakup bantuan langsung, dapat berupa jasa, waktu atau uang. Misalnya keluarga memberikan uang saku tambahan karena adanya aktifitas tambahan di sekolah, atau orang tua membelikan buku pelajaran untuk mendukung bidang yang sedang ia tekuni. Dukungan ini membantu individu dalam melaksanakan aktivitasnya.

4. Dukungan informatif, mencakup pemberian nasehat, petunjuk-petunjuk, saran- 
saran, informasi atau umpan balik. Dukungan ini membantu individu mengatasi masalah yang dihadapi. Informasi tersebut diperlukan untuk mengambil keputusan dan memecahkan masalah secara praktis. Keluarga memberikan informasi yang dibutuhkan individu untuk membantu menambah wawasan sebagai bahan pertimbangan dalam mengambil keputusan. Dukungan informatif ini juga membantu individu mengambil keputusan karena mencakup mekanisme penyediaan informasi, pemberi nasihat, dan petunjuk.

5. Dukungan jaringan sosial, dukungan ini mencakup perasaan keanggotaan dalam kelompok. Dukungan jaringan sosial merupakan perasaan keanggotaan dalam suatu kelompok, saling berbagi kesenangan dan aktivitas sosial.

\section{Metodologi Penelitian}

\section{A. Teknik Pengumpulan Data}

Dalam penelitian ini menggunakan beberapa metode pengumpulan data yakni observasi, menggunakan kuisoner, serta studi kepustakaan.

\section{Populasi}

Menurut Sugiyono (Sugiyono, 2009) Populasi merupakan wilayah generalisasi yang terdiri atas objek/subjek yang memiliki kuantitas dan karakteristik tertentu yang ditetapkan oleh peneliti untuk dipelajari dan kemudian ditarik kesimpulannya. Dalam penelitian ini menggunakan populasi yakni 85 mahasiswa yang terdiri dari semester II,

\begin{tabular}{|c|c|c|c|c|c|c|}
\hline \multirow{2}{*}{$\begin{array}{c}\text { Kriteri } \\
\text { a } \\
\text { Peneliti } \\
\text { an }\end{array}$} & \multicolumn{2}{|c|}{ X1.1 } & \multicolumn{2}{|c|}{ X1.2 } & \multicolumn{2}{|c|}{$\mathbf{X 1 . 3}$} \\
\hline & $\mathbf{F r}$ & $\%$ & Fr & $\%$ & $\mathbf{F r}$ & $\%$ \\
\hline $\begin{array}{c}\text { Sangat } \\
\text { Tidak } \\
\text { Setuju }\end{array}$ & 2 & $2,4 \%$ & 4 & $\begin{array}{c}4,7 \\
\%\end{array}$ & 1 & $1,2 \%$ \\
\hline $\begin{array}{l}\text { Tidak } \\
\text { Setuju }\end{array}$ & 11 & $13 \%$ & 18 & $\begin{array}{c}21,2 \\
\%\end{array}$ & 4 & $4,7 \%$ \\
\hline Netral & 8 & $9,4 \%$ & 9 & $\begin{array}{c}10,6 \\
\%\end{array}$ & 9 & $\begin{array}{c}10,6 \\
\%\end{array}$ \\
\hline Setuju & 36 & $\begin{array}{c}42,3 \\
\%\end{array}$ & 26 & $\begin{array}{c}30,6 \\
\%\end{array}$ & 37 & $\begin{array}{c}43,5 \\
\%\end{array}$ \\
\hline $\begin{array}{l}\text { Sangat } \\
\text { Setuju }\end{array}$ & 28 & $\begin{array}{c}32,9 \\
\%\end{array}$ & 28 & $\begin{array}{c}32,9 \\
\%\end{array}$ & 34 & $40 \%$ \\
\hline Total & 85 & $\begin{array}{c}100 \\
\%\end{array}$ & 85 & $\begin{array}{c}100 \\
\%\end{array}$ & 85 & $\begin{array}{c}100 \\
\%\end{array}$ \\
\hline
\end{tabular}

IV dan VI

\section{B. Teknik Analisis Data}

Setelah semua data terkumpul, maka langkah selanjutnya adalah menganalisis data. Analisis data yang penulis gunakan pada penelitian ini adalah menggunakan analisis kuantitatif.

\section{Analisis regresi berganda}

Analisis regresi berganda digunakan untuk mengetahui seberapa besar pengaruh variabel bebas yaitu : faktor kepribadian individu (X1), prospek lapangan kerja (X2), citra perguruan tinggi (X3), dan dukungan keluarga (X4) terhadap keputusan memilih program studi Pariwisata. Adapun persamaan regresi linier berganda yang digunakan dalam penelitian ini sebagai berikut :

$\mathrm{Y}=\mathrm{a}+\mathrm{b} 1+\mathrm{X} 1+\mathrm{b} 2+\mathrm{X} 2+\mathrm{b} 3+\mathrm{X} 3+\mathrm{b} 4+\mathrm{X} 4+\varepsilon$

Dimana:

$\mathrm{Y} \quad=$ keputusan memilih program studi Pariwisata

$$
\begin{array}{ll}
\mathrm{a} & =\text { Konstanta } \\
\mathrm{b} 1, \mathrm{~b} 2, \mathrm{~b} 3= & \text { Koefisien regresi } \\
\mathrm{X} 1 & =\text { kepribadian individu } \\
\mathrm{X} 2 & =\text { Faktor prospek lapangan kerja } \\
\mathrm{X} 3 & =\text { Faktor citra perguruan tinggi } \\
\mathrm{X} 4 & =\text { Faktor dukungan keluarga } \\
\varepsilon & =\text { Error }
\end{array}
$$

\section{Hasil dan Diskusi}

\section{Tanggapan Responden}

Angka indeks digunakan untuk mengetahui persepsi umum responden mengenai sebuah variabel yang diteliti (Augusty, 2006). Angka indeks untuk masing-masing variabel adalah sebagai berikut :

\section{Variabel Faktor Kepribadian Individu (X1)}

\section{Tabel 1}

\section{Tanggapan Responden Terhadap Variabel Faktor Kepribadian Individu (X1)}




\begin{tabular}{ccccccc}
\hline $\begin{array}{c}\text { Kriteria } \\
\text { Penelitian }\end{array}$ & \multicolumn{2}{c}{ X1.1 } & \multicolumn{2}{c}{ X1.2 } & \multicolumn{2}{c}{ X1.3 } \\
& Fr & $\%$ & Fr & $\%$ & Fr & $\%$ \\
\hline $\begin{array}{c}\text { Sangat } \\
\text { Tidak }\end{array}$ & 2 & $2,4 \%$ & 4 & $4,7 \%$ & 1 & $1,2 \%$ \\
$\begin{array}{c}\text { Setuju } \\
\text { Tidak }\end{array}$ & 11 & $13 \%$ & 18 & $21,2 \%$ & 4 & $4,7 \%$ \\
$\begin{array}{c}\text { Setuju } \\
\text { Netral }\end{array}$ & 8 & $9,4 \%$ & 9 & $10,6 \%$ & 9 & $10,6 \%$ \\
Setuju & 36 & $42,3 \%$ & 26 & $30,6 \%$ & 37 & $43,5 \%$ \\
& & & & & & \\
Sangat & 28 & $32,9 \%$ & 28 & $32,9 \%$ & 34 & $40 \%$ \\
Setuju \\
Total & 85 & $100 \%$ & 85 & $100 \%$ & 85 & $100 \%$ \\
\hline & & & & & &
\end{tabular}

Sumber :data primer yang diolah, 2018

Pada pernyataan pertama sebanyak $42,4 \%$ responden memberikan tanggapan setuju pada pernyataan yang mengatakan bahwa "Memilih program studi Pariwisata karena sesuai dengan minat saya". Hal ini dikarenakan sebagian mahasiswa telah mengetahui apa yang mereka inginkan sesuai dengan minatnya. Pada pernyataan kedua sebanyak 32,9\% responden memberikan tanggapan sangat setuju yang menyatakan bahwa program studi pariwisata adalah pilihan pertama saya. Hal ini dikarenakan mahasiswa telah memikirkan dengan baik untuk melanjutkan pendidikannya dengan mengambil jurusan pariwisata di bangku perkuliahan. Pada pernyataan ketiga sebanyak $43,5 \%$ menyatakan setuju bahwa mereka ingin mendalami tentang ilmu Pariwisata di perguruan tinggi. Hal ini dikarenakan mahasiswa siap mempelajari halhal yang berkaitan dengan pariwisata selama masa perkuliahan mereka.

\section{Variabel Faktor Prospek Lapangan Kerja (X2)}

Tabel 2

Tanggapan Responden Terhadap Variabel Faktor Prospek Lapangan Kerja (X2)

\begin{tabular}{|c|c|c|c|c|c|c|c|c|}
\hline \multirow{2}{*}{$\begin{array}{l}\text { Kriteri } \\
\text { a } \\
\text { peneliti } \\
\text { an }\end{array}$} & \multicolumn{2}{|c|}{ X2.1 } & \multicolumn{2}{|c|}{$\mathrm{X} 2.2$} & \multicolumn{2}{|c|}{$\mathbf{X} 2.3$} & \multicolumn{2}{|c|}{$\mathbf{X 2 . 4}$} \\
\hline & fr & $\%$ & $\mathbf{F r}$ & $\%$ & fr & $\%$ & Fr & $\%$ \\
\hline $\begin{array}{l}\text { Sangat } \\
\text { Tidak } \\
\text { Setuju }\end{array}$ & 0 & 0 & 0 & 0 & 0 & 0 & 0 & 0 \\
\hline $\begin{array}{l}\text { Tidak } \\
\text { Setuju }\end{array}$ & 1 & $1,2 \%$ & 0 & 0 & 3 & $3,5 \%$ & 1 & $1,2 \%$ \\
\hline Netral & 2 & $2,4 \%$ & 3 & $3,5 \%$ & 11 & $13 \%$ & 8 & $9,4 \%$ \\
\hline Setuju & 47 & $\begin{array}{c}55,3 \\
\%\end{array}$ & 39 & $\begin{array}{c}45,9 \\
\%\end{array}$ & 43 & $\begin{array}{c}50,6 \\
\%\end{array}$ & 48 & $\begin{array}{c}56,5 \\
\%\end{array}$ \\
\hline $\begin{array}{l}\text { Sangat } \\
\text { Setuju }\end{array}$ & 35 & $\begin{array}{c}41,1 \\
\%\end{array}$ & 43 & $\begin{array}{c}50,6 \\
\%\end{array}$ & 28 & $\begin{array}{c}32,9 \\
\%\end{array}$ & 28 & $\begin{array}{c}32,9 \\
\%\end{array}$ \\
\hline Total & 85 & $\begin{array}{c}100 \\
\%\end{array}$ & 85 & $\begin{array}{c}100 \\
\%\end{array}$ & 85 & $\begin{array}{c}100 \\
\%\end{array}$ & 85 & $\begin{array}{c}100 \\
\%\end{array}$ \\
\hline
\end{tabular}

Sumber : data primer yang diolah, 2018
Pada indikator pertama sebanyak 55,3\% responden menyatakan setuju pada pernyataan lulusan program studi pariwisata dapat bersaing didunia kerja. Hal ini dikarenakan setelah lulus dari program studi pariwisata para lulusan telah mendapatkan keterampilan selama masa perkuliahan dan para lulusan siap bersaing dengan lulusan perguruan tinggi lainnya saat memasuki dunia kerja.

Pada indikator kedua sebanyak 50,6\% menyatakan sangat setuju pada pernyataan program studi pariwisata memiliki peluang kerja yang luas. Hal ini dikarenakan industri pariwisata pada saat ini mengalami perkembangan yang pesat.

Pada indikator ketiga sebanyak 50,6\% menyatakan setuju pada pernyataan Jurusan Pariwisata Politeknik Negeri Samarinda memiliki kerjasama yang baik dengan dunia kerja. Hal ini dikarenakan Jurusan Pariwisata terus mengalami perubahan menjadi lebih baik dan melakukan kerjasama agar memudahkan lulusan saat memasuki dunia kerja. Pada indikator keempat sebanyak 56,5\% responden menyatakan setuju pada pernyataan dengan banyaknya industri pariwisata saat ini, lulusan program studi pariwisata memiliki kesempatan untuk mendapatkan pekerjaan sesuai bidangnya. Hal ini dikarenakan mahasiswa yakin bahwa dengan berkembang pesatnya industri pariwisata maka pekerjaan dibidang pariwisata juga akan semakin luas dan terbuka lebar bagi lulusan pariwisata.

\section{Variabel Faktor Citra Perguruan Tinggi (X3)}

Tabel 3

Tanggapan Responden Terhadap Variabel Faktor Citra Perguruan Tinggi (X3)

\begin{tabular}{|c|c|c|c|c|c|c|c|c|}
\hline Kriter & \multicolumn{2}{|c|}{ X3.1 } & \multicolumn{2}{|c|}{ X3.2 } & \multicolumn{2}{|c|}{ X3.3 } & \multicolumn{2}{|c|}{ X3.4 } \\
\hline $\begin{array}{c}\text { ia } \\
\text { Peneli } \\
\text { tian }\end{array}$ & fr & $\%$ & Fr & $\%$ & $\begin{array}{l}\mathbf{F} \\
\mathbf{r}\end{array}$ & $\%$ & fr & $\%$ \\
\hline $\begin{array}{l}\text { Sangat } \\
\text { Tidak } \\
\text { Setuju }\end{array}$ & 0 & 0 & 1 & $\begin{array}{c}1,2 \\
\%\end{array}$ & 1 & $\begin{array}{c}1,2 \\
\%\end{array}$ & 0 & 0 \\
\hline $\begin{array}{l}\text { Tidak } \\
\text { Setuju }\end{array}$ & 5 & $\begin{array}{c}5,9 \\
\%\end{array}$ & 3 & $\begin{array}{c}3,5 \\
\%\end{array}$ & $\begin{array}{l}1 \\
4\end{array}$ & $\begin{array}{c}16,5 \\
\%\end{array}$ & 2 & $\begin{array}{c}2,4 \\
\%\end{array}$ \\
\hline Netral & 11 & $\begin{array}{l}13 \\
\%\end{array}$ & 13 & $\begin{array}{l}15, \\
3 \%\end{array}$ & $\begin{array}{l}1 \\
1\end{array}$ & $\begin{array}{l}13 \\
\%\end{array}$ & 15 & $\begin{array}{c}17, \\
6 \\
\%\end{array}$ \\
\hline Setuju & 48 & $\begin{array}{l}56, \\
4 \%\end{array}$ & 47 & $\begin{array}{l}55, \\
3 \%\end{array}$ & $\begin{array}{l}4 \\
0\end{array}$ & $\begin{array}{l}47 \\
\%\end{array}$ & 43 & $\begin{array}{c}50, \\
6 \\
\%\end{array}$ \\
\hline $\begin{array}{l}\text { Sangat } \\
\text { Setuju }\end{array}$ & 21 & $\begin{array}{l}24, \\
7 \%\end{array}$ & 21 & $\begin{array}{l}24, \\
7 \%\end{array}$ & $\begin{array}{l}1 \\
9\end{array}$ & $\begin{array}{c}22,3 \\
\%\end{array}$ & 25 & $\begin{array}{c}29, \\
4 \\
\%\end{array}$ \\
\hline Total & 85 & $\begin{array}{l}10 \\
0 \%\end{array}$ & 85 & $\begin{array}{c}100 \\
\%\end{array}$ & $\begin{array}{l}8 \\
5\end{array}$ & $\begin{array}{c}100 \\
\%\end{array}$ & 85 & $\begin{array}{c}10 \\
0 \\
\%\end{array}$ \\
\hline
\end{tabular}


Sumber : data primer yang diolah, 2018

Sebanyak 56,4\% responden menyatakan setuju pada indikator pertama yang menyatakan bahwa kualitas Politeknik Negeri Samarinda sangat baik. Hal ini dikarenakan Politeknik Negeri Samarinda telah diketahui sebagai perguruan tinggi vokasi yang telah memiliki nama baik di lingkungan masyarakat.

Pada indikator kedua sebanyak $55,3 \%$ menyatakan setuju pada pernyataan Politeknik Negeri Samarinda adalah perguruan tinggi yang dapat dipercaya dan diandalkan. Hal ini karena Politeknik Negeri Samarinda merupakan perguruan tinggi yang telah menghasilkan lulusan terbaik yang tersebar di banyak tempat pekerjaan.

Pada indikator ketiga sebanyak $47 \%$ responden menjawab setuju dalam menanggapi pernyataan Politeknik Negeri Samarinda memberikan pelayanan kepada mahasiswa dengan baik. Hal ini dikarenakan mahasiswa merasa nyaman dalam melakukan perkuliahan di Politeknik Negeri Samarinda.

Pada pernyataan akhir sebanyak $50,6 \%$ responden menyatakan setuju bahwa Politeknik Negeri Samarinda memiliki citra yang baik di masyarakat. Hal ini dikarenakan Politeknik Negeri Samarinda terus memberikan perubahan kearah yang lebih baik dan memiliki lulusan yang baik di masyarakat.

4. Variabel Faktor Dukungan Keluarga (X4)

$$
\text { Tabel } 4
$$

Tanggapan Responden Terhadap Variabel Faktor Dukungan Keluarga (X4)

\begin{tabular}{|c|c|c|c|c|c|c|c|c|}
\hline \multicolumn{2}{|c|}{ Kriteri } & \multicolumn{2}{|c|}{ X4.1 } & \multicolumn{2}{|c|}{ X4.2 } & \multicolumn{2}{|c|}{$\mathrm{X} 4.3$} & X4.4 \\
\hline $\begin{array}{c}\text { Kriter } \\
\text { ia } \\
\text { Peneli } \\
\text { tian } \\
\end{array}$ & $\mathrm{fr}^{\mathrm{Y}}$ & $1 \%$ & $\mathrm{fr}^{Y}$ & $\%$ & fr & .3 & fr & $\%$ \\
\hline $\begin{array}{l}\text { Sangat } \\
\text { Tidak } \\
\text { Setuju }\end{array}$ & 5 & $\begin{array}{c}5,9 \\
\%\end{array}$ & 1 & $\begin{array}{c}1,2 \\
\%\end{array}$ & 1 & $\begin{array}{c}1,2 \\
\%\end{array}$ & 3 & $3,5 \%$ \\
\hline $\begin{array}{l}\text { Tidak } \\
\text { Setuju }\end{array}$ & 6 & $\begin{array}{l}7,1 \\
\%\end{array}$ & 3 & $\begin{array}{c}3,5 \\
\%\end{array}$ & 2 & $\begin{array}{c}2,4 \\
\%\end{array}$ & 1 & $1,2 \%$ \\
\hline Netral & 10 & $\begin{array}{c}11 \\
8 \\
\%\end{array}$ & 6 & $\begin{array}{l}7,1 \\
\%\end{array}$ & 15 & $\begin{array}{c}17 \\
6 \\
\%\end{array}$ & 12 & $\begin{array}{c}14,2 \\
\%\end{array}$ \\
\hline Setuju & 35 & $\begin{array}{c}41, \\
1 \\
\%\end{array}$ & 55 & $\begin{array}{c}64 \\
7 \\
\%\end{array}$ & 49 & $\begin{array}{c}57 \\
6 \\
\%\end{array}$ & 54 & $\begin{array}{c}63,5 \\
\%\end{array}$ \\
\hline $\begin{array}{l}\text { Sangat } \\
\text { Setuju }\end{array}$ & 29 & $\begin{array}{c}34, \\
1 \\
\%\end{array}$ & 20 & $\begin{array}{c}23 \\
5 \\
\%\end{array}$ & 18 & $\begin{array}{c}21 \\
2 \\
\%\end{array}$ & 15 & $\begin{array}{c}17,6 \\
\%\end{array}$ \\
\hline Total & 85 & $\begin{array}{c}10 \\
0 \\
\%\end{array}$ & 85 & $\begin{array}{c}10 \\
0 \\
\% \\
\end{array}$ & 85 & $\begin{array}{c}10 \\
0 \\
\%\end{array}$ & 85 & $\begin{array}{c}100 \\
\%\end{array}$ \\
\hline
\end{tabular}

\begin{tabular}{|c|c|c|c|c|c|c|c|c|}
\hline $\begin{array}{c}\text { a } \\
\text { Penelit } \\
\text { ian }\end{array}$ & $\mathbf{F r}$ & $\%$ & Fr & $\%$ & fr & $\%$ & $\mathbf{F r}$ & $\%$ \\
\hline $\begin{array}{l}\text { Sangat } \\
\text { Tidak } \\
\text { Setuju }\end{array}$ & 0 & 0 & 1 & $\begin{array}{c}1,2 \\
\%\end{array}$ & 0 & 0 & 1 & $\begin{array}{c}1,2 \\
\%\end{array}$ \\
\hline $\begin{array}{l}\text { Tidak } \\
\text { Setuju }\end{array}$ & 3 & $\begin{array}{l}3 \\
5 \\
\%\end{array}$ & 2 & $\begin{array}{c}2,4 \\
\%\end{array}$ & 0 & 0 & 8 & $\begin{array}{c}9,4 \\
\%\end{array}$ \\
\hline Netral & 4 & $\begin{array}{c}4, \\
7 \\
\%\end{array}$ & 10 & $\begin{array}{c}11 \\
8 \\
\%\end{array}$ & 5 & $\begin{array}{c}5, \\
9 \\
\%\end{array}$ & 11 & $\begin{array}{l}13 \\
\%\end{array}$ \\
\hline Setuju & 42 & $\begin{array}{l}49 \\
, 4 \\
\%\end{array}$ & 48 & $\begin{array}{c}56, \\
4 \\
\%\end{array}$ & 53 & $\begin{array}{l}62 \\
3 \\
\%\end{array}$ & 42 & $\begin{array}{c}49, \\
4 \\
\%\end{array}$ \\
\hline $\begin{array}{l}\text { Sangat } \\
\text { Setuju }\end{array}$ & 36 & $\begin{array}{c}42 \\
, 4 \\
\%\end{array}$ & 24 & $\begin{array}{c}28, \\
2 \\
\%\end{array}$ & 27 & $\begin{array}{r}31 \\
8 \\
\%\end{array}$ & 23 & $\begin{array}{l}27 \\
\%\end{array}$ \\
\hline Total & 85 & $\begin{array}{c}10 \\
0 \\
\%\end{array}$ & 85 & $\begin{array}{c}10 \\
0 \\
\%\end{array}$ & 85 & $\begin{array}{c}10 \\
0 \\
\%\end{array}$ & 85 & $\begin{array}{c}10 \\
0 \\
\%\end{array}$ \\
\hline
\end{tabular}

Sumber : data primer yang diolah, 2018

Pada pernyataan pertama sebanyak 49,4\% responden menyatakan setuju bahwa keluarga memberikan kepercayaan terhadap apa yang saya pilih atau kerjakan. Hal ini dikarenakan mahasiswa telah meyakinkan keluarganya bahwa mereka telah memilih keputusan yang tepat bagi diri mereka.

Pada pernyataan kedua sebanyak $56,4 \%$ responden menyatakan setuju bahwa keluarga selalu memberikan pandangan baik mengenai pilihan program studi saya. Hal ini dikarenakan mahasiswa mendapatkan respon yang baik saat membicarakan tentang perkuliahan.

Pada pernyataan ketiga sebanyak $62,3 \%$ responden menyatakan setuju bahwa orang tua memberikan fasilitas yang dapat menunjang kegiatan selama masa perkuliahan. Hal ini dikarenakan mahasiswa mendapatkan kemudahan dari orang tua berupa fasilitas yang terus diberikan orang tua untuk kelancaran mahasiswa selama menjalani masa perkuliahan.

Pada pernyataan terakhir sebanyak $49,4 \%$ responden menyatakan setuju bahwa keluarga memberikan nasehat dalam menyelesaikan permasalahan di perkuliahan. Hal ini dikarenakan saat mahasiswa meminta solusi atau nasehat kepada keluarga, keluarga menanggapinya dengan baik.

\section{Variabel Keputusan Memilih Program Studi (Y)}

Tabel 5

Tanggapan Responden Terhadap Variabel Keputusan Memilih Program Studi (Y) 


\section{Sumber : data primer yang diolah, 2018}

Pada indikator pertama sebanyak $41,1 \%$ responden setuju bahwa keputusan memilih program studi pariwisata karena sesuai dengan keinginan saya. Hal ini dikarenakan mahasiswa telah yakin bahwa program studi pariwisata dapat memberikan yang terbaik sesuai dengan keinginan atau minat mereka.

Pada indikator kedua sebanyak 64,7\% responden setuju bahwa faktor prospek lapangan kerja mempengaruhi dalam keputusan memilih program studi pariwisata. Hal ini dikarenakan saat memilih program studi pariwisata mahasiswa mengetahui bahwa prospek lapangan kerja industri pariwisata luas. Pada indikator ketiga sebanyak $57,6 \%$ responden menyatakan setuju pada pernyataan melihat dari reputasi perguruan tinggi yang baik, mempengaruhi dalam keputusan memilih program studi pariwisata. Hal ini dikarenakan berkuliah di perguruan tinggi yang memiliki reputasi baik akan memudahkan mereka setelah lulus dari perguruan tinggi tersebut.

Pada pernyataan terakhir sebesar $63,5 \%$ responden menjawab setuju bahwa faktor dukungan keluarga mempengaruhi dalam keputusan memilih program studi pariwisata. Hal ini karena pada saat memilih suatu jurusan atau program studi, mahasiswa akan membicarakan dan mencari solusi yang baik kepada keluarganya.

\section{Analisis Regresi Berganda}

Analisis regresi berganda digunakan dalam penelitian ini dengan tujuan untuk mengetahui ada tidaknya pengaruh variabel bebas terhadap variabel terikat. Perhitungan statistic analisis regresi berganda menggunakan SPSS for Windows versi 16.0. Hasil pengolahan data menggunakan SPSS adalah sebagai berikut :

\section{Tabel 6}

Hasil Regresi

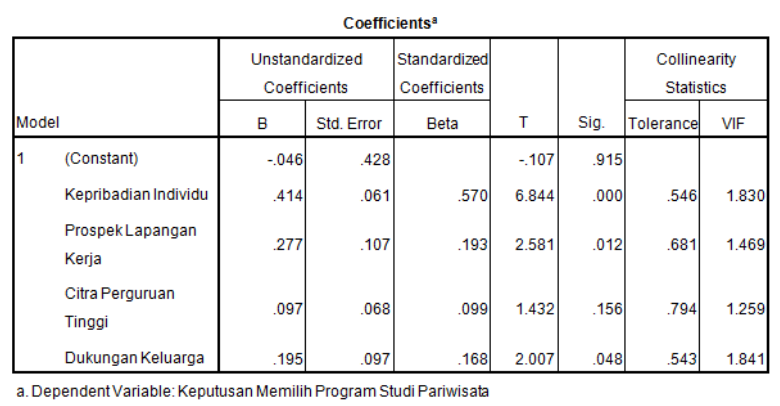

Sumber : data primer yang diolah, 2018

Berdasarkan pada hasil analisis yang telah dilakukan, maka persamaan regresi yang terbentuk adalah sebagai berikut :

Hasil uji coefficients pada variabel

A. Variabel kepribadian individu dikemukan nilai (a) $=-0,046$, nilai $\mathrm{B}=0,414$ dan nilai $t_{\text {hitung }}=6,844$ dengan nilai sig 0,000

B. Variabel prospek lapangan kerja dikemukan nilai (a) $=-0,046$, nilai $\mathrm{B}=0,277$ dan nilai $t_{\text {hitung }}=2,581$ dengan nilai sig 0,012

C. Variabel citra perguruan tinggi dikemukan nilai (a) $=-0,046$, nilai $\mathrm{B}=0,097$ dan nilai $\mathrm{t}_{\text {hitung }}=1,432$ dengan nilai sig 0,156

D. Variabel dukungan keluarga dikemukan nilai (a) $=-0,046$, nilai $\mathrm{B}=0,195$ dan nilai $\mathrm{t}_{\text {hitung }}=2,007$ dengan nilai sig 0,048

Dari hasil data tersebut apabila ditulis dalam bentuk standarlized dari persamaan regresinya adalah sebagai berikut :

$\mathrm{Y}=-0,046+0,414_{1}+0,277_{2}+0,097_{3}+0,195_{4}$

Dimana :

$\mathrm{Y}=$ Keputusan Memilih

$\alpha=$ Konstanta

$\mathrm{X} 1=$ Faktor Kepribadian Individu

$\mathrm{X} 2$ = Faktor Prospek Lapangan Kerja

X3 = Faktor Citra Perguruan Tinggi

X4 = Faktor Dukungan Keluarga

a. Koefisien regresi pada variabel kepribadian individu (X1) sebesar 0,414 adalah positif. Dan nilai beta sebesar 0,570. Dengan demikian hipotesa yang berbunyi : "pengaruh kepribadian individu pada keputusan memilih program studi". Adalah terbukti kebenarannya.

b. Koefisien regresi pada variabel prospek lapangan kerja (X2) sebesar 0,277 adalah positif. Dan nilai beta sebesar 0,193 . Dengan demikian hipotesa yang berbunyi : "pengaruh prospek lapangan kerja pada keputusan memilih program studi". Adalah terbukti kebenarannya.

c. Koefisien regresi pada variabel citra perguruan tinggi (X3) sebesar 0,097 adalah positif. Dan nilai beta sebesar 
0,099. Dengan demikian hipotesa yang berbunyi: "pengaruh citra perguruan tinggi pada keputusan memilih program studi”. Adalah terbukti kebenarannya.

d. Koefisien regresi pada variabel dukungan keluarga (X4) sebesar 0,195 adalah positif. Dan nilai beta 0,168 . Dengan demikian hipotesa yang berbunyi: "pengaruh dukungan keluarga terhadap keputusan memilih program studi”. Adalah terbukti kebenarannya.

Berdasarkan hasil penelitian tersebut dapat dilihat bahwa faktor kepribadian memiliki hasil yang tinggi atau dominan, dengan demikian pengaruh dari sikap mahasiswa dalam memilih program studi sangat menentukan yang bersangkutan untuk memilih sebuah program studi pariwisata. Sikap kepribadian ini sudah terbentuk saat yang bersangkutan masih sekolah Kejuruan, dimana dunia pariwisata memiliki dayak tarik tersendiri. Berikutnya faktor penentu berikutnya adalah prospek lapangan kerja, banyak peluang dunia kerja menjadi pilihan bagi mahasiswa untuk memilih program pariwisata, saat ini Kalimantan timur ditunjuk menjadi calon ibu kota negara dan ditambah lagi adanya pembangunan hotel baru. Faktor ketiga adalah dukungan keluarga. Peranan keluarga menggambarkan seperangkat perilaku antar pribadi, sifat, kegiatan yang berhubungan dengan pribadi dalam posisi dan situasi tertentu(Sri Lestari, 2012), faktor keempat adalah citra perguruan tinggi. Meskipun faktor citra perguruan tinggi tidak dominan namun sangat memiliki pengaruh untuk memilih program studi pariwisata. Politeknik Negeri Samarinda memiliki pengalaman panjang dalam hal pendidikan, pengajaran supaya bisa menghasilkan lulusan yang berkualitas.

\section{Kesimpulan}

Keluarga merupakan lingkungan pertama yang dialami seorang anak manusia ketika dilahirkan ke dunia. Dalam perkembangan selanjutnya keluarga juga merupakan lingkungan utama dalam pembentukan kepribadian seorang anak manusia(Wahy, 2012).

Keluarga adalah pembentuk dan sumber pempelajaran bagi anak, oleh karena itu pihak Kampus POLNES perlu mengadakan kegiatan bersama orang tua yang membahas tentang pendidikan anak di perguruan tinggi. Ketika anak masih SMK atau SMU mereka belum punya banyangan tentang mau kuliah dimana.

Berdasarkan hasil penelitian ini bahwa kepribadian mahasiswa sangat menentukan ketika mereka ingin memilih Program Studi Pariwiwsata. Selain itu prospek lapangan kerja dapat menjadi alasan mereka memilih program studi. Selanjutnya peran keluarga juga sangat membantu ketika mahasiswa ingin menentukan masa depan mereka.

Politeknik Negeri Samarinda sebagai tempat mahasiswa mendapatkan ilmu saatnya selalu melakukan perbaikan-perbaikan baik fasilitas maupun sistem pengajarannya. Supaya citra perguruan tinggi menjadi lebih baik serta menjadi perguruan tinggi unggulan bagi mahsiswa yang ingin mencari ilmu dan pengalaman di dunia pendidikan tinggi.

\section{References}

[1]. Augusty, F. (2006). Metode Penelitian Manajemen: Pedoman Penelitian untuk skripsi, Tesis dan Disertai Ilmu Manajemen. Universitas Diponegoro.

[2]. Bilson Simamora. (2008). Panduan Riset Perilaku Konsumen (Edisi keti). Gramedia Pustaka Utama.

10 Friedman, M. . (2010). Buku Ajar Keperawatan Keluarga: Riset, Teori dan Praktek. EGC.

[4]. Indra Novianto Adibayu Pamungkas. (2019). Pentingnya Komunikasi Orang Tua dan Anak dalam Memilih Jurusan Kuliah. Kumparan. https://kumparan.com/indraimi/pentingnya-komunikasi-orang-tuadan-anak-dalam-memilih-jurusankuliah-1rWRoQJZLTg/full

[5]. J. P Chaplin. (n.d.). Kamus Lengkap Psikologi (Edisi terj). Raja Grafindo Persada.

[6]. Krugman, P. R. and M. O. (2003). International Economics: Theory and Policy (6th Edition). Pearson Education.

[7]. Lestari, S. (2018). Peran Teknologi dalam Pendidikan di Era Globalisasi. Edureligia; Jurnal Pendidikan Agama Islam, 2(2), 94-100. 
[8]. Lestari, Sri. (2012). Penanaman Nilai dan Penanganan Konflik dalam Keluarga. Prenada Media Group.

[9]. M Ridki Zarkasyi. (2013). Entrepreneur Radikal. Renebook.

[10]. Nuryadin, Muhammad Teguh, Marijati Sangen, S. A. A. (2017). Analisis faktor-faktor yang mempengaruhi mahasiswa dalam memilih Program Studi Pada Jurusan Administrasi Bisnis Politeknik Negeri Banjarmasin. Jurnal Wawasan Manajemen, Vol. 5, No.

[11]. Pendidikan, D. N. (2008). Kamus Besar Bahasa Indonesia (Keempat, p. 368). Balai Pustaka.

[12]. Philip Kotler, K. L. K. (2010). Prilaku Konsumen. Erlangga.

[13]. Prodjo, W. A. (n.d.). 8 Tips Jitu Memilih Program Studi Kuliah. Kompas.Com. https://edukasi.kompas.com/read/2019/ 11/11/19560321/8-tips-jitu-memilihprogram-studi-kuliah?page $=$ all

[14]. Rohmat. (2012). Pilar Peningkatan Mutu Pendidikan. Cipta Media Aksara.

[15]. Sarafino. (2000). Health Psychology: Biopsychososial Interaction. John
Wilky and Sons Inc.

[16]. Schiffman, L. G. and L. L. K. (2011). Consumer Behavior (Tenth Edit). Pearson Education.

[17]. Setiadi nugroho. (2013). Prilaku Konsumen (Edisi Revi). Kencana.

[18]. Sugiyono. (2009). Metode Penelitian Kuantitatif, Kualitatif dan $R \& D$. Alfabeta.

[19]. Wahy, H. (2012). Keluarga sebagai basis pendidikan pertama dan utama. Jurnal Ilmiah DIDAKTIKA, VOL. XII $N, 245-258$.

[20]. Yusuf LN, J. N. (2007). Teori Kepribadian. PT Remaja Rosdakarya.

[21]. Zainal Anawar. (2012). A-Z Psikologi, berbagai kumpulan topik psikologi. Andi Offset.

[22]. Zuyun Nela. (2013). Hubungan antara dukungan keluarga dengan motivasi melanjutkan Sekolah Menengah Kejuruan (SMK). Jurnal Online, 5. http://www.jogjapress.com/ 